\title{
Strengths and weaknesses of the 100 Resilient Cities Initiative in Southern Europe: Rome and Athens' experiences
}

\author{
Adriana Galderisi ${ }^{1}$, Giada Limongi ${ }^{*}$ and Konstantina-Dimitra Salata ${ }^{2}$
}

\begin{abstract}
Cities are nowadays faced with an unprecedented crisis, due above all to the impacts of climate change and the increasing social inequalities, which require innovative approaches and more effective tools. Resilience is widely interpreted as a key principle to re-frame urban policies, paving the way to cross-sectoral urban strategies capable of better coping with contemporary challenges. This contribution focuses in particular on the 100 Resilient Cities (100RC) Initiative, launched by the Rockefeller Foundation and addressed to support cities all over the world in developing and implementing strategies capable of increasing urban resilience in the face of multiple shocks and stresses, including climate change. In detail, based on the comparative analysis of two case studies, Rome and Athens, this paper aims at providing insights on the main strengths and weaknesses of cities'resilience-building processes developed under the 100RC Initiative and at deeply analyzing the contribution of the delivered Resilience Strategies to the improvement of cities' capacities to cope with contemporary challenges and above all with the increasing impacts of climate change.
\end{abstract}

Keywords: Resilient Cities, 100 Resilient Cities, Climate change, Social inequalities, Resilient strategies

\section{Enhancing Cities' Resilience: why and how}

Cities nowadays are at the core of the international planning debate, due both to their rapid growth and changing geographies (Brenner and Schmid 2015) and to the multiple and often interconnected factors, such as the impacts of natural and climate-related hazards, the environmental degradation or the increasing social inequalities, which are threatening their livability as well as their future development (Zhang and Li 2017). Just a few years ago, the Italian planner Bernardo Secchi recognized the impacts of climate change and the increasing social inequalities as the crucial aspects of a "new urban question" (Secchi 2013). However, these aspects are not independent of each other, not only because of the adverse social consequences of climate change, which could contribute

\footnotetext{
*Correspondence: giada.limongi@unicampania.it

${ }^{1}$ Department of Architecture and Industrial Design, University

of Campania Luigi Vanvitelli, Aversa, Italy

Full list of author information is available at the end of the article
}

to radicalize current inequalities (Beck 2010), but also to the potential influence of climate policies on economic inequalities as well as on social cohesion and wellbeing (Hallegatte and Rozenberg 2017; Markkanen and AngerKraavi 2019).

In the face of the contemporary and interconnected crisis induced by climate change and increasing inequalities, innovative and more effective approaches and tools are required (Albrechts et al. 2020). The Agenda 2030, and namely its goal 11-"make cities inclusive, safe, resilient and sustainable"-has clearly underlined the need of "(...) adopting and implementing integrated policies and plans towards inclusion, resource efficiency, mitigation and adaptation to climate change, resilience to disasters" (UN 2015). However, the progresses towards this target are still limited (UN 2019): greenhouse gas (GHG) emissions continue to grow up, even though at different rates in different countries, and the increasing inequalities in income and wealth levels, currently exacerbated by the pandemic and consequent economic crisis, risk 
to undermine the overall effort towards the Sustainable Development Goals.

Thus, how to push a progress towards the goals and targets established by the Agenda 2030? What innovative and effective approaches and tools can we deploy in order to support cities in developing and implementing integrated policies capable of addressing contemporary challenges?

The polysemic concept of resilience, to which multiple meanings have been attributed over the years, also due to its migration across different disciplinary fields (Alexander 2013; Galderisi 2018), in the field of urban research is rapidly changing "from an emerging research topic direction into mainstream one" (Zhang and Li 2017). Nowadays, it is widely interpreted as a key principle to "frame scientific and political discourses on cities" (Yamagata and Sharifi 2018) and to pave the way to cross-sectoral urban strategies capable of overcoming sectoral approaches (Gabellini 2018).

However, resilience is still an ambiguous concept since it is interpreted according to different approaches, which vary from the most 'conservative' ones, referable to the systems' ability to absorb shocks or stresses, thus ensuring their persistence, to the 'transformative' ones, referable to system's ability to radically transform when changing ecological, economic or social conditions make the current state unsustainable (Bene et al. 2012; Wang and Yamashita 2015). Moreover, although the resilience concept is increasingly associated with the sustainability one, the relationships between them are still poorly defined. The documents underlying the Sustainable Development Goals and particularly the Goal 11 narrowly define or use interchangeably the concepts of resilience and sustainability (Elmqvist et al. 2019), and the Agenda 2030 does not provide a definition of the key terms-sustainable and resilient-identified as crucial to the future development of human settlements by the goal 11.

Despite the lack of agreed definitions as well as of sound and shared methods to analyze, assess and improve urban resilience, in the last decade the initiatives aimed at enhancing it in the face of the increasingly pressing social and environmental challenges have multiplied around the world. Thanks to numerous international initiatives addressed to translate resilience into practice, by providing both a theoretical frame and operational tools to support a resilience building process at city scale, this concept has gained prominence in the urban agendas all over the world. The on-going initiatives, while sharing the common goal of enhancing cities' capacity to deal with more and more pressing environmental, social and economic challenges, largely differ from each other, as they are promoted by different organizations and pursue different goals. The most relevant ones, in terms of number of involved cities, are the 'Making Cities Resilient' Campaign, launched in 2013 by the United Nations International Strategy for Disaster Reduction (UNISDR) that is still on-going, and the 100 Resilient Cities (100RC) Initiative, launched in 2013 by the Rockefeller Foundation that ended in 2019. While the former is addressed to provide cities with operational tools for coping with acute shocks induce by natural and man-made hazards, the latter, grounding on a holistic approach to cities, aims at providing them with financial and operational tools in order to support the development and implementation of strategies capable of increasing cities' resilience in the face of a wide range of stresses and shocks, ranging from migrations to water shortage, from earthquakes to climate change (The Rockefeller Foundation and Arup 2016).

This paper focuses on the 100RC Initiative: in detail, "The 100 RC Initiative" section provides a brief presentation of the Initiative as well as of the supporting tools offered to the participating cities to analyze, assess and improve their resilience; "Cases description: Rome and Athens, two paradigmatic examples of the "new urban question" section details why Rome and Athens, two cities that due to their current environmental and social features can be considered as paradigmatic examples of the "new urban question", have been selected as case studies and provides a brief description of their common features and peculiarities; "Rome and Athens: the resilience building process" section and "Rome and Athens Resilience strategies: the focus on climate issues" section provide a comparative analysis of the resilience building processes in the selected case studies, highlighting strengths and weaknesses of the two processes and focusing in detail on the contribution provided by the Resilience Strategies to the improvement of cities' capacities to cope with the increasing impacts of climate change. The final section critically discusses the outcomes, positive and negative, of the 100RC Initiative.

\section{The 100 RC Initiative}

The 100RC Initiative was launched in the 2013 by the Rockefeller Foundation, a private foundation established in 1913 to promote the well-being of humanity throughout the world, by focusing on four core commitments: to end energy poverty, to achieve health for all, to nourish the world, and to expand economic opportunity. ${ }^{1}$

Mirroring the broad goals of the Rockefeller Foundation, the 100RC Initiative was designed to financially and technically support cities all over the world in enhancing

\footnotetext{
${ }^{1}$ https://www.rockefellerfoundation.org/about-us/our-history/.
} 
their resilience in the face of multiple and complex challenges. In particular, engaged cities were expected to improve their performances in the face of a wide range of acute shocks, such as earthquakes, floods or fires, and chronic stresses, such as unemployment, migrations, food and water shortage, etc. rather than preventing or mitigating the loss of assets due to a specific hazard (The Rockefeller Foundation and Arup 2015).

The 100RC Initiative refers to a definition of resilience interpreted as "the capacity of individuals, communities, institutions, businesses, and systems within a city to survive, adapt, and grow no matter what kinds of chronic stresses and acute shocks they experience" (The Rockefeller Foundation and Arup 2015). Such a definition, which seems to combine an 'adaptive' perspective, addressed to adjust cities to a constantly changing context, with a 'transformative' one, aimed at radically changing them according to modified contexts and circumstances, results from a line of studies focused on the resilience of socio-ecological adaptive systems and namely on their ability to adapt and significantly transform with or without external disturbance (Gotham and Campanella 2010; Shaw 2012). However, despite the provided definition, some documents available on the initiative's website clearly emphasize the aim to support cities in developing their capacity to recover quickly and effectively when crises arise, ${ }^{2}$ proving a greater affinity with a more 'conservative' approach to resilience, rooted in the engineering resilience (Holling 1996) and largely widespread in disaster studies.

In order to guide the selected cities along a resilience building process, the Rockefeller Foundation in cooperation with the global design firm Arup and based on an extensive and documented research work, ${ }^{3}$ developed a set of tools allowing cities to analyze and assess their own resilience. The key tools to analyze and assess cities' resilience are the 'City Resilience Framework' (CRF) and the City Resilience Index (CRI). The CRF is a circular model composed of different rings and sectors: it identifies four dimensions (Health \& Wellbeing; Economy \& Society; Infrastructure \& Environment; and Leadership \& Strategy) and 12 key goals ( 3 for each dimension) that represent the main outcomes that a resilient city should aim for. Hence, building on the CRF, the CRI provides a set of 52 indicators and adequate metrics for measuring and assessing city's resilience. Each indicator is related to the seven qualities that a resilient system should strengthen to effectively withstand, respond and adapt to shocks and stresses, and namely: inclusiveness, integration,

\footnotetext{
${ }^{2}$ https://www.rockefellerfoundation.org/blog/valuing-resilience-dividend/.

${ }^{3}$ https://www.arup.com/projects/city-resilience-index.
}

reflectiveness, resourcefulness, robustness, redundancy, and flexibility. The overall set of indicators can be measured through 156 questions and the responses can be then re-aggregated in respect to the 12 goals of the CRF (The Rockefeller Foundation and Arup 2016).

The main goal of the $100 \mathrm{RC}$ Initiative is to drive the selected cities towards the delivering of a Resilience Strategy, built through a participatory process guided by the appointed Chief Resilience Officer (CRO) and a local resilience team supported by international consultants (such as Arup). The semi-standardized resilience building process should last from 6 to 9 months and is generally structured in two main phases (Fitzgibbons and Mitchell 2019): a first one addressed to carry out a baseline assessment of city's resilience, based on CRF and CRI, to select the shocks and stresses that each city intends to primarily address, and to define the Preliminary Resilience Assessment; a second one addressed to deliver the Resilience Strategy, intended as a living document to be continuously fine-tuned as foreseen actions are implemented and priorities are addressed (Berkowitz and Kramer 2018).

All the Resilience Strategies developed under the 100RC Initiative have been designed according to a common structure that includes pillars, goals and actions. Goals and actions are aligned with the CRF goals and indicators that the Strategy, based on the previous assessment, aims at improving (Croese et al. 2020).

The outlined structure of the resilience building process within the frame of the $100 \mathrm{RC}$ Initiative, even though it provided cities all over the world with a systematic and common framework to assess and improve their resilience according to their own priorities, raised also some questions related, for example, to the influence of the CRF-considered as a universally valid frame of reference-in shaping local goals and actions, also when local issues did not neatly fit into the 100RC tools (Sutherland et al. 2019) or, even, to the real importance assigned to the involvement of local stakeholders. The limited time given to cities to deliver the Resilience Strategies seems to conflict, in fact, with the large emphasis put on the stakeholders' engagement, especially for cities still predominantly characterized by top-down decision-making processes, as most cities in Southern Europe as well as in the Global South.

In the frame of the resilience building process outlined by the 100RC Initiative, this paper focuses on how this process has been unfolded in two case selected studies, Athens and Rome. In the following sections commonalities and peculiarities of the two case studies as well as positive and negative outcomes of each process will be outlined, and the contribution of the delivered Resilience Strategies to the improvement of climate resilience in the selected cities will be explored. 


\section{Cases description: Rome and Athens, two} paradigmatic examples of the 'new urban question' In Europe, the 100RC initiative was joined by nine Northern European cities (including five from the UK) and seven Mediterranean cities (Athens and Thessaloniki in Greece, Rome and Milan in Italy, Barcelona in Spain, Lisbon in Portugal and Belgrade in Serbia). Among the involved European cities, two Mediterranean cities, Rome and Athens, which are respectively the capital cities of Italy and Greece, have been selected as case studies. The two cities show, in fact, numerous similarities related, for example, to their climatic profile and to the multiple hazards they are prone to; moreover, both cities have a thousand-year history behind them whilst showing nowadays a social, economic and environmental crisis making their future development highly uncertain.

In the following sections, the profiles of the two selected cities as well as the main common challenges they have to face have been briefly outlined. In detail, besides some general information related to their administrative demographic and morphological features, the main environmental and social criticalities (such as land take, soil sealing, population aging; etc.) as well as the main shocks and stresses the two cities suffered in the last years have been described in order to highlight why Rome and Athens can be considered as paradigmatic examples of the two main facets of "new urban question" (Secchi 2013): the impacts of climate change and the growing social inequalities. Due to their features, the selected cases study could provide useful insights on the effectiveness of a resilience-based approach in tackling the different challenges threatening urban future development and, in particular, those related to climate impacts and their multiple consequences.

\section{Rome: the city profile}

Rome is the Italian capital and hosts about 2,900,000 inhabitants on a territorial surface of $1285 \mathrm{~km}^{2}$. It is one of the largest cities in Europe by population size and by territorial extension. Rome is the main city of the homonymous Metropolitan City that is divided into 121 municipalities, while the main city is divided into 15 administrative units. The Metropolitan City of Rome hosts more than four million inhabitants on a surface of $5363 \mathrm{~km}^{2}$.

The development of the city has been largely influenced by the local morphology and namely by the presence of the Tiber river. Since ancient times the river has represented one of the city's strengths, being a key element of its peculiar landscape, but also a weakness, due to its frequent flooding. Rome has long sought to balance the growing demand for urbanization with the fragility of its natural environment. In the last century, the population growth and the societal development let arise new demands, contributing to further exacerbate the fragile balance between the city and its natural environment (Resilient Rome 2018).

Current urban structure mirrors the demographic growth of the city over the years: about 500,000 inhabitants live in the city center, characterized by a very high population density, whilst about 1,600,000 inhabitants live in the post-war belt, and about 750,000 inhabitants live in the peripheral low-density areas ${ }^{4}$ (Resilient Rome 2016). The index of social disease highlights socioeconomic gaps, between the central districts and the suburbs, characterized by a severe marginalization. It ranges from -2.3 for the first central district to 4.9 for the sixth peripheral district (Municipality of Rome-General Accounting 2017). In addition, based on data provided by the Italian National Statistics Institute, the old age index increased from 150 in 2004 to 170 in 2019, and the number of resident foreign citizens has tripled in the last 15 years: the percentage of foreign citizens increased from $4.8 \%$ in 2004 to $13.4 \%$ in 2019.

The old age index and the increasing migration flows require more adequate services, capable to better cope with the needs of disadvantaged categories (elderly, immigrants, low income population), by increasing their opportunities to access public facilities, promoting social inclusion and ensuring higher levels of safety.

Rome is the Italian city with the highest absolute value of soil consumption ${ }^{5}$ in 2018 and 2019. This value ranges from very high values (about 70\%) recorded in the central historical districts to low values (about 15\%) registered in the peripheral ones (Munafò and Polverini 2019). The increase in the last two years is mostly due to the construction of new sealed areas, commercial areas, residential buildings and infrastructures in peripheral areas (Munafò 2019a, 2020). The average percentage of consumed soil for the whole Municipal area is about $24 \%$, and $22 \%$ is considered as permanent consumption. Finally, it has to be underlined that soil consumption, and above all the percentage of soil sealing in flood prone areas, have significantly exacerbated flood risk: almost

\footnotetext{
${ }^{4}$ Looking at the data provided by the Municipal Registry (2016), the average population density is about $2236 \mathrm{inh} / \mathrm{km}^{2}$. However, it ranges from more than $8000 \mathrm{inh} / \mathrm{km}^{2}$ in the city centre, to less than $2000 \mathrm{inh} / \mathrm{km}^{2}$ in the peripheral census units.

${ }^{5}$ It has to be noticed that at the European level it is commonly distinguished land take, intended as a measure of the surfaces converted from a natural/seminatural use into an urban or other artificial development, from soil sealing, intended as the portion of land that is effectively sealed (see https://soil4life.eu/en/il-consumo-del-suolo/). In Italy, available data provided by the National Institute for Environmental Safeguard and Research (ISPRA) include both concepts in the term 'soil consumption' (https://www. isprambiente.gov.it/it/attivita/suolo-e-territorio/il-consumo-di-suolo/defin izioni).
} 
$82 \%$ of the total consumption of soil in Rome occurred in flood prone areas with serious consequences on the expected damage due to extreme rainfalls (Munafò and Polverini 2018).

Moreover, soil sealing contributes to the phenomenon of the Urban Heat Island (UHI), even though it also depends on other factors such as layout of the urbanized areas, building materials, vegetation and winds. Considering the metropolitan area of Rome, the temperature variation between densely built artificial surfaces and rural areas is about $3{ }^{\circ} \mathrm{C}$ (Munafò 2019b). During the 2001-2013 summers the Land Surface Temperature (LST) reached $31{ }^{\circ} \mathrm{C}$ (Morabito et al. 2015). The phenomenon of the UHI represents a significant hazard factor especially for elderly that, as mentioned above, are constantly increasing.

Despite natural areas covering more than $60 \%$ of the Municipal surface, public green areas represent only the $5 \%$ of the total (Resilient Rome 2018). The difficult maintenance of the natural heritage, as well as of the historical and cultural heritage, is largely due to their quantity, diffusion and heterogeneity. The infrastructural networks also suffer from a lack of effective maintenance: the aging and scarcely maintained transport, water supply, waste disposal networks struggle more and more to satisfy population needs. The low efficiency of public transport contributes to a continuous growth of car-based mobility and, consequently, to the increase of greenhouse gas emissions and air pollution: high values of $\mathrm{NO}^{2}$ are currently reported both for the more densely populated areas and for the main roads with high traffic flows. ${ }^{6}$ In terms of governance, Rome suffers from the lack of integrated strategic frameworks, and cross-sectoral innovative policies (Coppola 2018).

\section{Athens: the city profile}

The City of Athens has a population of 664,046 inhabitants (2011 Census), living into an area of $37.954 \mathrm{~km}^{2}$. It covers the central part of the Attica Region ${ }^{7}$ (3.828.434 inhabitants in 2011) and it is one of the most densely built and populated municipalities in Greece. The Attica Region shows a complex and interesting morphological landscape, with the City of Athens located in the immediate vicinity of mountains, protected areas (Natura 2000 network, National Park), forests and coastal areas as well as the Port of Piraeus (the largest in Greece and one of the biggest in the Mediterranean area and Europe).

\footnotetext{
${ }^{6}$ http://qa.arpalazio.net/index.php.

7 The Attica Region is divided into eight Regional Units, one of which is the Regional Unit of Central Athens, in which the City of Athens is located.
}

The City of Athens is characterized by a high population density, aging (and in some areas very low quality) built urban fabric, narrow streets and lack of green (public) open spaces. Rapid urbanization, uncontrolled land take and residential development, frequently built without any permission, has led to a high percentage of soil sealing (more than $80 \%$ of its surface is waterproof), to the depletion of peri-urban green areas along with the covering of a considerable portion of its natural water network (streams) (Resilient Athens 2017). According to the data provided by the CORINE land cover, in 2018 the total artificial area (LEAC categories) for Central Athens ${ }^{8}$ was equal to the $74 \%$ of the total surface. ${ }^{9}$

The Region of Attica is considered one of the most exposed regions to natural hazards (particularly earthquakes, floods, heat waves and forest fires) in Greece. Moreover, the aforementioned features of the City of Athens further exacerbate phenomena such as UHI, flash-floods and low levels of air quality (Chalkias et al. 2015; Kartalis et al. 2017; Maloutas and Spirellis 2019; Resilient Athens 2017). The major flash floods and forest fires that hit the Attica Region in the last years are a direct result of this complex situation and clearly demonstrate the insufficient planning framework and practice, the lack of city's preparedness to cope with hazardous events and, overall, the high degree of physical and institutional vulnerability.

The serious socio-economic crisis (an aftermath of the global financial crisis of 2007-2008) aggravated the already high human, social and institutional pre-crisis vulnerability, especially against natural hazards and, also, led to severe austerity policies and measures. Among the main consequences of the resulting recession were declining incomes, growing personal debt, high real estate taxes as well as increasing levels of unemployment, poverty and homelessness, leading to violence and civil unrest. Moreover, austerity led to significant cuts in local government's budget and thus in public works and social services, which have deeply affected the most vulnerable population. At the same time, the large flows of refugees and immigrants in the city intensified the social pressures, created new marginalities inside already existing marginalities (Monno and Serreli2020) and strengthened the feeling of mistrust between citizens and local Authorities (Chalkias et al. 2015; Maloutas and Spirellis 2019; Resilient Athens 2017). Based on a report of the International Organization for Migration (IOM) Office

\footnotetext{
${ }^{8}$ In some cases, data for wider spatial areas have been used, since data for the City of Athens are not available.

${ }^{9}$ https://www.eea.europa.eu/data-and-maps/dashboards/land-cover-andchange-statistics.
} 


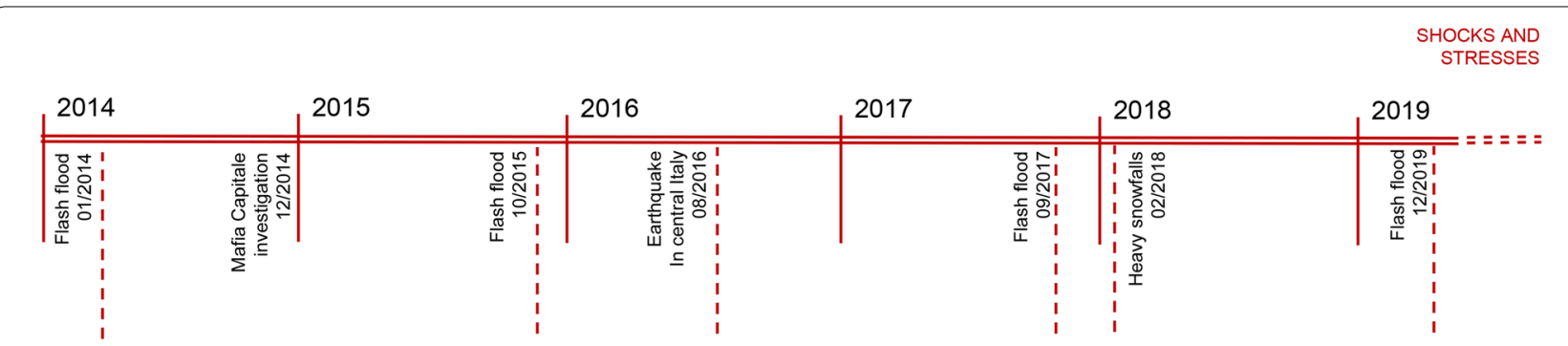

Fig. 1 Occurred shocks and stresses in Rome Source: Resilient Rome (2016)

\begin{tabular}{|l|l|l|l|l|l|}
\hline \\
\hline \hline
\end{tabular}

in Greece (2020), in January 2020, 7276 migrants $^{10}$ were living in mainland open accommodation sites (camps) in the Region of Attica, one of which, "Eleonas Long-Term Accommodation Site", is located within the municipality of Athens, accommodating 1796 people (with a total capacity of 1.850 people) (IOM-Office in Greece 2020). Regarding ESTIA Accommodation Scheme, ${ }^{11}$ in March 2020, there were 11,651 asylum seekers and recognized refugees living in the Region of Attica (UNHCR GREECE 2020).

However, this shock has provoked a wave of citizens' mobilization and solidarity networks, and the growth of civil society responses, including non-profit organizations and informal groups. Gradually, it became clear that refugees may represent an opportunity for the city's crucial problem of sharply declining and aging population. This change in demographic features affects the city's cultural mix and identity. It is worth noting that the City of Athens, in contrast with other municipalities of the Region, is a socially mixed area, characterized by the existence of vertical social differentiation ${ }^{12}$ (Maloutas and Karadimitriou 2001; Maloutas and Spirellis 2015). City's urban structure with multi-story residential building and mixed uses has enabled, to some extent, this

\footnotetext{
10 Including asylum seekers and beneficiaries of international protection.

11 People accommodated in rental apartments and whole buildings.

12 There is however a northwest part of the municipality mainly occupied by lower-middle class.
}

vertical differentiation among social classes and ethnic identities, thus avoiding the creation of urban 'ghettos' (Resilient Athens 2017).

\section{Rome and Athens: common challenges}

Both Rome and Athens have experienced several changes throughout their history, and they stand now at the crossroad of multiple challenges, many of which common to other cities in Europe and beyond, but also of opportunities for triggering more responsible urban development processes.

Climate-related impacts, such as flash floods, heat waves, forests fires, represent a major challenge in both cities, also due to the highly vulnerable built environment: high population density, inadequate infrastructures, lack of public green areas as well as of effective maintenance policies result in a limited capacity of both cities to cope with more and more frequent climaterelated hazards (Figs. 1, 2). Moreover, in the last decade economic crisis and migration flows significantly affected both cities determining a significant increase in poverty and social inequalities levels, in particular in Athens, where large-scale flows of refugees, combined to the severe consequences in terms of loss of jobs, reduction of incomes and increase of taxes, led to acute social conflicts.

Thus, Rome and Athens can be nowadays considered as paradigmatic examples of the main facets of the "new urban question" (Secchi 2013): the impacts of climate 


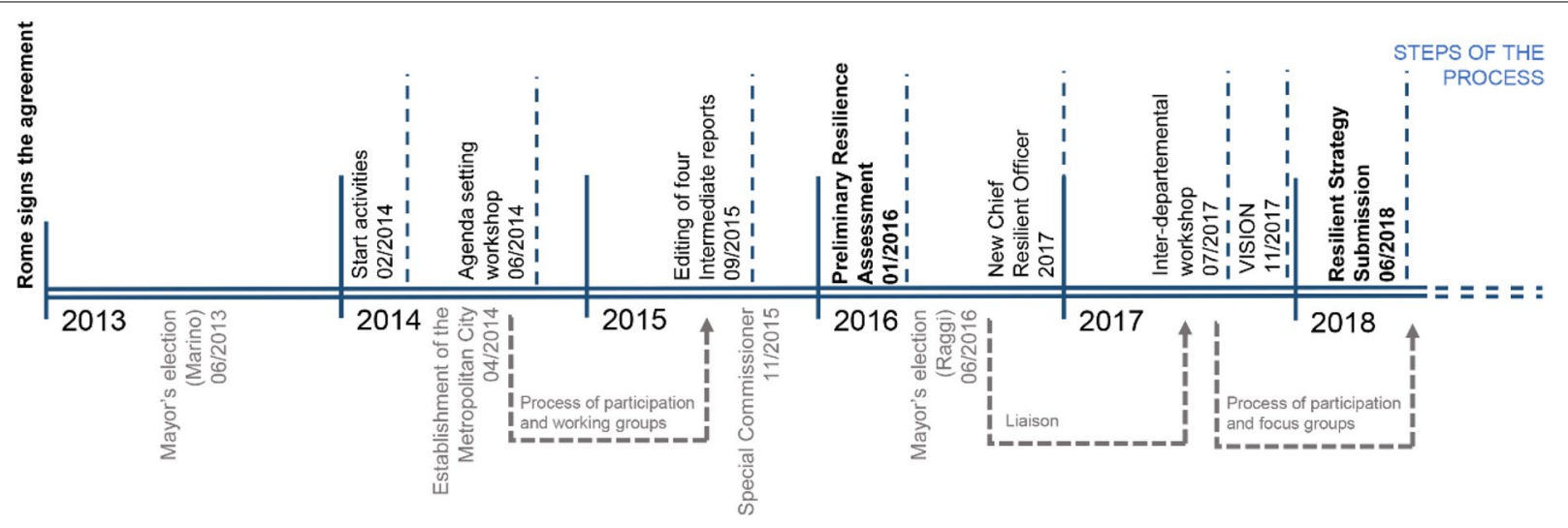

Fig. 3 Main steps of the Resilience Strategy building process in Rome. Source: Resilient Rome (2016)

change and the growing social inequalities. Thus, the selected cases study could provide useful insights on the effectiveness of a resilience-based approach in tackling the most relevant interconnected challenges threatening urban future development.

\section{Rome and Athens: the resilience building process}

Following an application submitted by the cities themselves, Rome and Athens were selected to be part of the 100RC Initiative, respectively in 2013 and in 2014. Both of them followed, although with slightly different timing, the semi-standardized process suggested by the Rockefeller Foundation to deliver the Preliminary Resilience Assessment followed by the Resilience Strategy.

In 2013, Rome was selected as one of the first 32 cities to be part of the 100RC network; in the same year the Chief Resilience Officer (CRO) and a devoted working team were established. In June 2014, with the Agenda Setting Workshop, the working team gave the start to the resilience building process. The first phase of the process, aimed at outlining the reference scenario for the Resilience Strategy, led to the Preliminary Resilience Assessment (PRA) in 2016 (Fig. 3). During the first phase, the working team engaged local stakeholders through:

- focus groups, involving representatives of competent authorities in the field of infrastructures and transport networks, water management, technological network companies, departments for environmental and cultural heritage protection;

- surveys and workshops, involving professional and citizen associations, companies, and citizens (Resilient Rome 2016).

These activities allowed the team, supported by external experts, identifying strengths and weaknesses of Rome as well as shocks and stresses that affect the city and prioritizing them according to the stakeholders' perception. Based on these activities, in 2015 the Team drafted 4 intermediate reports, including the Stakeholder Engagement Plan, and in January 2016 published the PRA that identified the main shocks and stresses that Rome had to cope with, the most critical assets and the five main challenges to be addressed.

Following the release of the PRA, Rome has gone through a slowdown of the activities due to the establishment of a Special Commissioner to administer the City. After the establishment of the new City Government, in September 2017, a new CRO was appointed and the new Resilience Steering Committee (RSC) and Resilience Team established. Both of them were mostly composed by Deputy Mayors and members of different Municipal Departments, such as cultural policies, urban planning, environmental sustainability, heritage and housing policies, youth and social policies, economic development, digital policies, tourism, and labor policies. This transition led to a review of the previously identified challenges, according to the political agenda of the new Mayor, and significantly affected the timing of the process.

Hence, after the selection of the new CRO in September 2017, the renewed team supported by the external experts from the ARUP group, whilst the first phase of the process had been supported by the ICLEI, outlined the final Resilience Strategy that was officially launched in June 2018. The final Resilience Strategy outlined a vision for an inclusive and supportive city with an exceptional natural, historical and cultural heritage, capable of safeguarding its past and developing it by promoting environmental sustainability, economic development, and public well-being (Resilient Rome 2018). 
The engagement of Rome in the 100RC Initiative was part of a wider action promoted by the Urban Transformation and Environment Department and aimed at launching urban innovation pathways in a context scarcely oriented to innovation (Tocci 2015) and characterized by a significant lack of internal resources (Coppola 2016).

Athens was selected in 2014 (one of the 35 cities selected in the second round) to join the 100RC Initiative. In the spring of 2015, through the Agenda Setting Workshop (in which 130 Athenians were involved), the framework and the methods of the 100RC program were presented. The CRO was appointed in January 2016, while the Office of Resilience and Sustainability (ORS) was established in February 2016 and gained an official status as part of the Mayor's Office in December 2016 (Government Gazette No 3812/B'/28-11-2016). The ORS, supported by the ARUP's external experts, laid the foundations for drafting and implementing the Resilience Strategy. Moreover, the RSC was established to provide interdisciplinary input and guidance throughout all the phases (conceptualization, drafting, implementation, monitoring) of the process aimed at delivering the Resilience Strategy. It involved an interdisciplinary group of stakeholders from different governmental, academic and nonprofit institutions covering a broad range of expertise and led by the Mayor of Athens (Resilient Athens ADDMA SA 2016; Resilient Athens 2017).

Stakeholders' engagement was one of the most important goals of Athens' Strategy: hence, the mapping of relevant stakeholders and the development of an integrated Stakeholder Engagement \& Communication Plan were the first steps of the process (Resilient Athens ADDMA SA 2016; Resilient Athens 2017). Thus, during the first phase of the drawing up of the Athens' Strategy (February-June 2016) and based on the methodology established by the 100RC Initiative, three tools were used to identify the city's critical assets, shocks, stresses and vulnerabilities:

- Perceptions Tool: the personal views of various stakeholders on what makes Athens resilient were gathered through interviews, online surveys, focus groups, workshops, conferences and meetings. A wide range of stakeholders was approached (prompted by the 100RC program) with the aim to give voice to city groups that are usually excluded from the decision-making process. Thus, the different initiatives involved city districts' council members, city staff and elected officials, central government authorities, architects, urban planners, start-uppers, tour guides, young entrepreneurs, CSOs, NGOs, migrant women, homeless, street paper vendors and elders. In total, 365 stakeholders were engaged, 171 stakeholders from the civil society, 100 from the public administration, 49 businesses and 45 experts (academic, administrative, architects, urbanists, etc.),

- Assets \& Risks Tool: the natural and man-made resources of the city in combination with the unexpected crises that threaten or may threaten Athens, were documented in collaboration with a group of academic and administrative experts on natural hazards but also with representatives of the municipality and public organizations, and

- Actions Tool: 451 actions (initiatives, policies, strategies, projects, studies, strategic plans) were documented (most of them were collected by the Municipality of Athens but also from the Region, the Ministry, various institutions and the civil society).

Based on these activities, in July 2016, the PRA was released: it shaped the vision for a resilient Athens-a city open, green, proactive and vibrant-and presented 5 discovery areas that Athens had to explore in detail in the second phase, in order to identify the opportunities that could contribute to enhance city resilience.

Then, in the period from March to June 2017, the Athens Resilience Strategy was drafted and discussed with the Mayor of Athens, the city Council, the municipal Executive Committee, the RSC and the municipal political parties. Its official public launch was held on June 13, 2017. In total, 140 organizations and 900 citizens participated in 40 workshops, conferences or public events. Phase III of the process, which started in July 2017, included the launch of the One Year Action Plan aimed at supporting the implementation of the Strategy (Fig. 4). In May 2018, the municipality of Athens conducted an assessment of the 3 years of ORS, in order to monitor the course of implementation (Resilient Athens ADDMA SA 2016; Resilient Athens 2017).

It is worth underlining that, even though Athens joined the 100RC Initiative in the second round (1 year later than Rome), it managed to fill the temporal gap, by surpassing Rome in terms of speed of the Strategy building process. Also, while the process in Athens was linear, in Rome it was slowed down by the change of CRO and Resilience Team as well as by a redesign of the preliminary vision according to the new Mayor's agenda.

The comparison between the two processes highlights some differences in the character of the leading actors and namely in the composition of the RSC: while in Rome involved actors are mainly representatives of local institutions, Athens opened to a broader range of external experts (such as academics, representatives of NGOs and of some professional categories, etc.). 


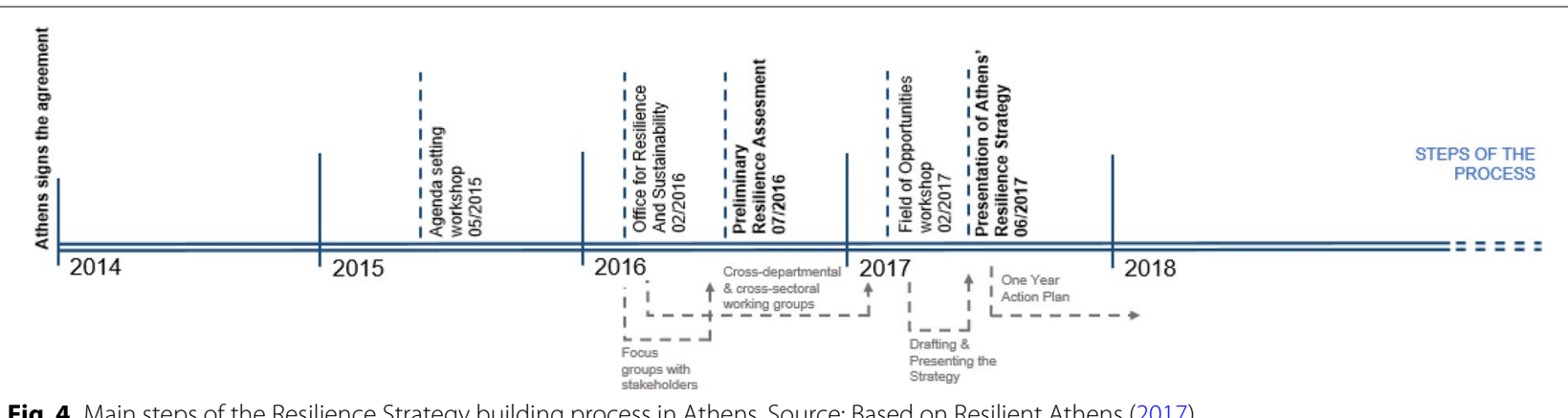

Fig. 4 Main steps of the Resilience Strategy building process in Athens. Source: Based on Resilient Athens (2017)

In both cities the Agenda Setting Workshop was an opportunity to trigger a participatory, cross-sectoral and innovative decision-making process, by engaging a number of stakeholders, in cities for long characterized by a limited participation of citizens in decision-making processes as well as by a scarce cooperation between different sectors of the public administration. According to the semi-standardized process set up by the 100RC Initiative, in fact, each city had to engage a wide range of stakeholders, covering a broad spectrum of groups and expertise, in the different phases of the resilience building process. Stakeholders' engagement is considered crucial to all the steps of the resilience building process, enabling Resilience Teams to embrace different perspectives in defining both critical issues and innovative visions for the future development of cities. Moreover, it may contribute to increase stakeholders' awareness about challenges and opportunities of the context at stake, which can be very important to ensure the active engagement of stakeholders also in the following implementation of the Strategies.

However, it has to be outlined that both in Rome and in Athens, the stakeholders' engagement process is only roughly described in the PRAs: although devoted Stakeholder Engagement \& Communication Plans are explicitly mentioned in each PRA, these Plans are not available online.

The outcome of the two processes was the delivering of the Resilience Strategies that, as mentioned in "“'The 100 RC Initiative" section have been designed according to a common structure that includes pillars, goals and actions. However, within this common structure, each city, through the briefly described participatory process, has to select the peculiar shocks and stresses it intends to face and has to set its own priorities. This explains the differences among pillars, goals and actions identified by each city, revealing also the flexibility of the methodology provided by the 100RC Initiative.

\section{Rome and Athens Resilience strategies: the focus on climate issues}

This section focuses on the relevance attributed to climate issues by the Resilience Strategies carried out in the two selected case studies by deepening, in particular, the balance among mitigation and adaptation measures outlined in each context and the links among the Resilience Strategies and other plans and initiatives and namely with spatial planning tools.

The focus on climate issues derives from several reasons. First of all, in both cities, the issue of mitigation and adaptation to climate change, despite the importance attributed in the last two decades to this issue in international agendas, has been for long overshadowed by other priorities. Both cities, in fact, have gone through a long phase of economic and social crisis, which certainly did not contribute to identify climate issues as a priority. Nevertheless, both cities suffered some climaterelated events during the process aimed at building up the Resilience Strategy. In particular, in the case of Rome flash floods occurred on an annual basis in the time span 2014-2018 and a snowfall hit the city in 2018. Moreover, the seismic events, which hit a large area of central Italy between 2016 and 2017, contributed to increase the concern of citizens and decision-makers for the high fragility of the whole country in the face of natural hazards (Fig. 1). In the case of Athens, the Attica Region in the time span of reference was affected by several flash floods too (Fig. 2). Moreover, in 2018 severe wildfires hit the Region of Attica, with the heatwave that affected most of Europe in the summer of 2018, also contributing to the exacerbation of flames. However, these events are not reported in Fig. 2, since the City of Athens was not directly hit by the fires.

Secondly, climate change is more and more widely recognized as a cross-cutting issue, depending on and affecting different sectors, from transportation to water and land use management. Therefore, it requires the overcoming of the sectoral approach, still prevailing 
especially in the selected case studies, and the development of cross-sectoral strategies, capable of strengthening both vertical and horizontal cooperation among different government levels, different sectors and departments of a municipality. Hence, Resilience Strategies, thanks to the engagement of different stakeholders as well as to the creation of devoted Resilience Offices, represent a challenge for the two cities at stake, but also an opportunity to promote a more effective multi-sectoral cooperation and collaboration among different sectors of local administration.

Finally, whilst the importance of mitigation and adaptation policies is more and more widely recognized both in the political agenda and in the scientific debate all over the world, the doubts on the effectiveness of the strategies so far undertaken and the alarm for their likely failure is constantly increasing. Looking at the ranking provided by the 2019 Global Risk Report, the 'failure of climate change mitigation and adaptation policies' is placed at the second place in the top ten of the perceived global risks both in terms of likelihood (following the extreme weather events) and in terms of impact (WEF 2019). Hence, it is important to understand if the measures introduced by the Resilience Strategies have a follow-up in terms of implementation.

\section{Stresses, shocks and challenges to be faced in Rome and Athens}

In the case of Rome, the PRA provided a description of the current status of the city and, based on the opinions of the engaged stakeholders, defined both the most relevant shocks and stresses and the main challenges that the city had to face. In detail, climate-related events (flash floods, pluvial and river floods, landslides, sinkholes, heat wave) and natural hazards (earthquakes) have been identified as the most relevant shocks, while the numerous chronic stresses have been referred to the lack of integrated planning, to the soil, water and air pollution, to the loss of ecosystem services, to the poor maintenance of public areas, infrastructures and building, to the inadequacy of public transport and to the lack of citizenship (Fig. 5).

Moreover, the PRA identified five main challenges that Rome had to cope with: economic crisis and increasing vulnerability of population, integrated governance, quality of life, urban safety and climate change, maintenance of the city's heritage.

Athens' PRA described Athens' status, regarding the demographic and social analysis of the urban area, the economy, the physical and man-made infrastructures, the cultural resources, the development strategy, the funding tools as well as the administrative structure. Based on the three tools already described in "Rome and Athens: the resilience building process" section-the Perceptions, the Assets \& Risks and the Actions tools-shocks and stresses, as well as the main challenges that the city had to cope with, were identified. In the case of Athens, natural hazards (earthquakes) and climate-related events (heat waves and flash floods) were also perceived as important shocks to be faced, combined with civil unrest (largely due also to the pressure of the economic crisis) and cybercrime. Regarding chronic stresses (fewer were documented compared to Rome), the most relevant ones referred to the impacts of the economic crisis, to the aging infrastructures and to the constant increase of migration flows. The identified main challenges, also in this case five areas, ranged from the urban decay to climate impacts (Fig. 6).

Resilience strategies: relevance of climate related measures The Rome Resilience Strategy is based on four pillars, mirroring the strategic vision outlined for the city. In respect to each pillar, some priority actions, directly linked to the pillars, the key goals and the actions that will allow the city to achieve them have been identified (Fig. 7).

It is worth noting that in respect to the whole set of actions outlined by the Strategy (58 actions), 27 of them (representing about 46\%) are related to climate issues, with a prevalence of mitigation measures (16 actions) (Table 1). All climate related actions have been classified in terms of mitigation, adaptation or mixed measures.

In particular, the goal B, which is related to the Pillar II and addressed to promote urban regeneration, includes relevant mitigation actions related, for example, to the development and testing test of pilot projects of smart grids, nearly zero energy buildings and Positive Energy Blocks-aimed to improve the use of renewable energyand Positive Energy Districts-aimed to achieve a zero or positive energy balance in the urban districts-in the areas surrounding the railway stations of Tiburtina and Pietralata, or to the improvement of public transports to reduce climate-altering emissions. Still in the second pillar, the goal $\mathrm{G}$ is entirely devoted to adapting the city to the main impacts of climate change-heat waves and floods-through green and blue infrastructures as well as through specific campaigns aimed at increasing citizens' awareness. Finally, all the actions included in the fourth pillar are specifically addressed to climate mitigation or adaptation.

The remaining planned actions, according to the other challenges that the city should cope with, are mostly targeted to improve the efficiency and effectiveness of the different departments of the public administration, by promoting meanwhile a better integration among them; 


\begin{tabular}{lll}
\hline \hline Lack of integrated and updated planning & Flash floods \\
Insufficient communications and information shared by offices & River floods \\
Slow and inefficient bureaucracy & Flooding due to bad \\
surface water runoff \\
Limited access to broadband telecommunications & Earthquakes \\
Air, water and soil pollution & Sinkholes \\
Critical issues in the urban solid waste cycle & Landslides \\
Loss of ecosystem services & Heat wave \\
Degradation of a part of the areas and public buildings & Heavy snowfall \\
Lack of citizenship & Instability of trees \\
Aged infrastructure & Infrastructure failures \\
A high level of commuting & accidents \\
Inadequate public transportation system & Blackout \\
Limited redundancy and continuity of services and critical infrastructure & Vandalism \\
Increase in the number of arrivals of migrants with the right to asylum & Forest and weeds fires \\
Impoverishment of the population & Cybercrime \\
Housing emergency & \\
\hline
\end{tabular}

Economic recession and vulnerability of the population

Effective management of the impact that the global economic recession has had on employment, on social networks, on vulnerable groups, and on increased migration trends.

Integrated governance

Supporting efficient and effective governance of the city by encouraging better communications and transparent information as a result of the use of digital media and overcoming the limits caused by slow red tape procedures.

Quality of life

Encouraging well-being and the quality of urban life of citizens: from access to housing to the efficiency of public transport; from cultural projects to improving differentiation and recycling of postconsumption materials.

Land safety and climate change

Monitoring and planning to secure the region against geologic problems (earthquakes, opening of sinkholes, subsoil pollution, geological instability) and predicting and mitigating the impacts of climate change (heat islands, drought, floods, landslide, etc.).

Maintenance of the city's heritage

Protection, preservation and valorization of the ecological, cultural and landscape heritage of the city, by encouraging sustainable tourism, and urban regeneration processes.

Fig. 5 Rome: shocks, stresses, and challenges as perceived by the involved stakeholders

to restore and maintain cultural and natural heritage and to reduce marginality among the weakest social groups.

Athens' Resilience Strategy is also based on four pillars, mirroring the desired future conditions for the city. Every pillar includes different goals and each goal comprises a set of actions that, all together, will contribute to achieve the vision of the Strategy (Fig. 8).

Among the 44 actions included in the Strategy, those specifically addressed to counterbalance climate change have been identified, by distinguishing the ones that may contribute to the reduction of GHG emissions (mitigation actions) from those more related to the adjustment and regulation of urban system as well as to changes in behavior in order to better cope with the more frequent climate impacts (adaptation actions). Some actions, and namely those focused on the regeneration of urban districts or on the recovery of individual buildings, address both mitigation and adaptation (Table 2). This analysis indicates that about $45 \%$ of the actions concern climaterelated issues (20 out of 44 actions). Athens' Strategy, contrary to that one of Rome, devotes equal relevance to mitigation and adaptation measures, with a slightly more attention to adaptation.

Pillar II is almost entirely related to tackling climate change, comprising actions aimed at the development of action plans both for mitigation of and for adaptation to climate change. It also includes urban regeneration projects, a comprehensive mobility roadmap along with the establishment and management of energy, food and waste systems. In particular, its actions aim at integrating natural systems into the urban fabric (through the creation of green and blue infrastructures) and better managing green areas in order to support and enhance natural environment as well as promote residents' well-being and improve their quality of life. Pillar III is more focused on adaptation and preparation against challenges and crises. Pillar IV includes both mitigation and adaptation actions, such as the regeneration of unused spaces and abandoned lots as well as the creation of urban corridors, linking green areas with cultural landmarks. 


\begin{tabular}{|c|c|c|}
\hline 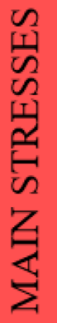 & $\begin{array}{l}\text { Depressed macroeconomic conditions } \\
\text { Aging infrastructure } \\
\text { Migration } \\
\text { Mistrust }\end{array}$ & $\begin{array}{l}\text { Earthquakes } \\
\text { Climate change related shocks (heat } \\
\text { waves, flash floods, poor air quality) } \\
\text { Civil unrest } \\
\text { Cybercrime }\end{array}$ \\
\hline 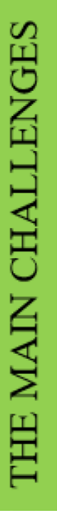 & \multicolumn{2}{|c|}{$\begin{array}{l}\text { Return to the neighborhood } \\
\text { Job creation - Upgrade public space in the neighborhoods - Fill empty buildings and stores - } \\
\text { Reverse desertification, aging and downgrade of the City. } \\
\text { From citizen's needs to impact - Effective governance } \\
\text { Enhance the link between Strategy/Planning and implementation inside the Municipality - } \\
\text { Management-Governance-Communication. } \\
\text { Best possible use of nature assets } \\
\text { Climate change - Heatwaves - Urban heat island - Effective energy use - Energy poverty - } \\
\text { Nature based solutions - Flooding phenomena. } \\
\text { Breaking through crisis } \\
\text { Open data and new information technologies in order to turn City's weaknesses into strengths - } \\
\text { Procedure optimization - Prevention and crisis management through innovation solutions. } \\
\text { Enhance social cohesion (cross-cutting) } \\
\text { Support civil society - Strengthen the communication among the Municipality and citizens. }\end{array}$} \\
\hline
\end{tabular}

Fig. 6 Athens: shocks, stresses and challenges as perceived by the engaged stakeholders

The remaining actions are mostly addressed to improve more transparent, effective and participatory governance mechanisms as well as to enhance social cohesion, above all at neighborhood scale. It has to be highlighted that, despite the relevance of the migration issue, the actions focused on this aspect are very limited compared to the total.

\section{The relationships with other urban strategies, plans, policies and initiatives}

One of the main opportunities for cities adopting a resilience strategy is related to the possibility of systematizing actions already included in other planning tools, framing them into a common and shared vision for future development.

The attention devoted to the building up of linkages among actions already included in other plans and programs, approved or with a still pending approval, is surely one of the strengths of the Rome Resilience Strategy that comprises numerous actions and measures already included in previous plans and projects (plans for urban regeneration, sustainable mobility, urban greening, etc.). The number of actions, already in progress at the time of the delivering of the Strategy, which have been framed into the Strategy itself is double in respect to the number of new actions. As clearly stated in the Strategy, this may contribute to guarantee both their implementation and a higher continuity in the city's development policies. All actions aimed at creating platforms for improving and disseminating knowledge, also through citizens' involvement, can be traced back to the Digital Agenda of Rome (2016), addressing the digital transformation of the public administration. These actions may contribute in the creation of a unique interface between public and private actors, stakeholders and decision makers, allowing updating and integrating data and information from different sectors. The establishment of a Resilience Office and the building up of an open data platform aim at reducing distances between citizens and local government as well as at creating an operation and management center capable of simplifying the integrated management of events in ordinary and emergency situations.

Furthermore, the participation into the 100RC network is also an opportunity to create synergies with other projects or initiatives aimed at enhancing urban resilience, such as Smart Mature Resilience (SMR) financed under the Horizon 2020 Program and developed in the time span 2016-2018. The aims of the SMR project were fully in line with the 100RC initiative and related to improve a multilevel and multisectoral coordination of all keystakeholders, from national and international levels to local institutions, including civil society, to ensure a better coordination among resilience policies. 


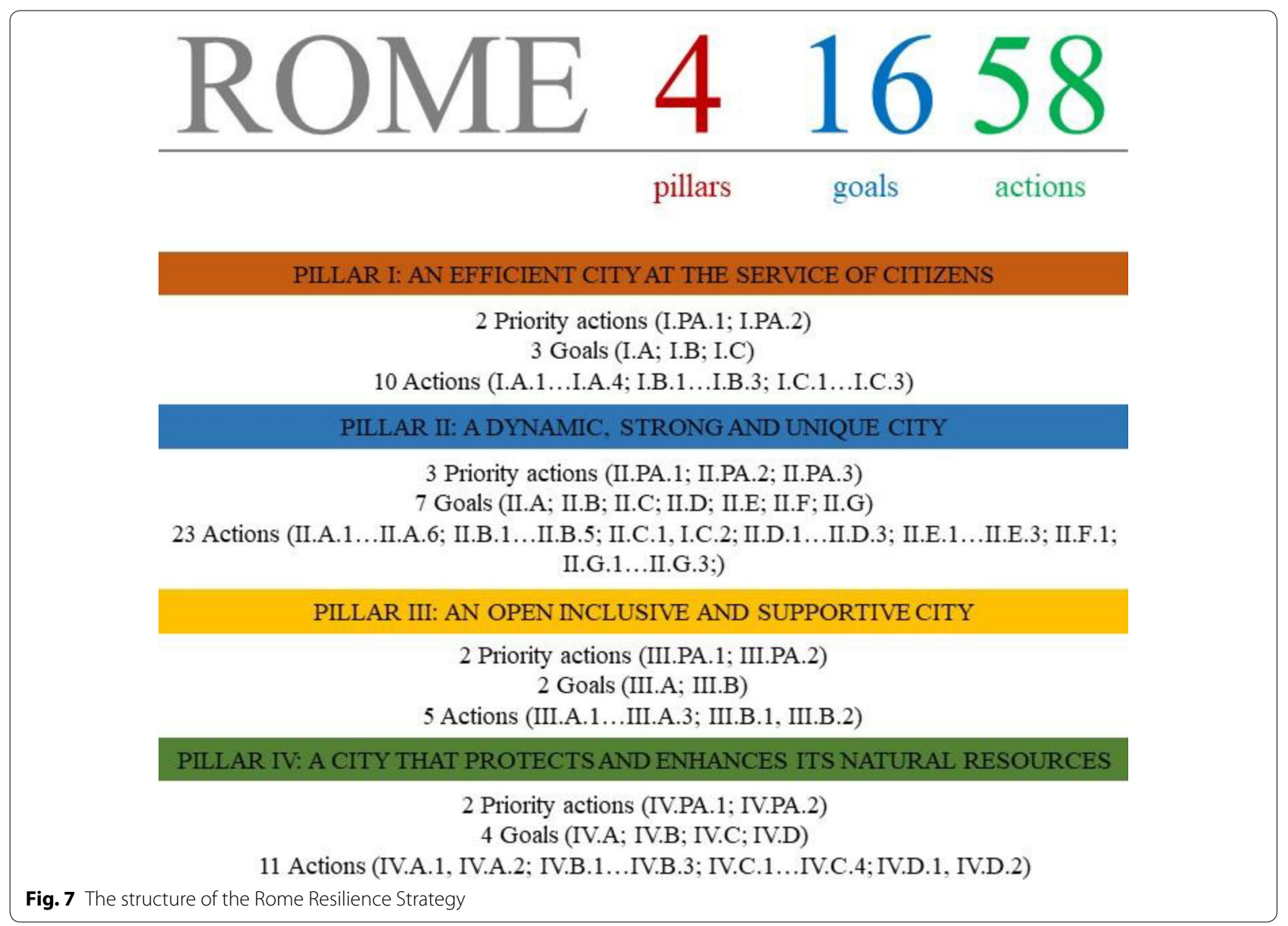

Moreover, Rome was already part of the C40 Network and one of the signatory cities of the first Covenant of Mayors. Hence, most of the actions classified as mitigation actions are already in progress, being part of the Sustainable Energy Action Plan, issued in 2013, although not fully implemented. On the opposite, adaptation actions are generally new, due to the lack of a previous adaptation plan: the Municipal Council, that took office in 2016, joined the New Covenant of Mayors for Climate and Energy in 2017, even though the Sustainable Energy and Climate Action Plan (SECAP) has to be still submitted. However, the actions addressed to counterbalance climate change, mostly included in the second and fourth pillars of the Resilience Strategy, and aimed at promoting urban regeneration, sustainable mobility, public green areas, are fully in line with the objectives established by the European Union for the SECAP.

Despite the numerous linkages among different planning tools carried out by the different sectors of the Municipality, the persisting lack of coordination among different Public Bodies has to be underlined. In particular, the actions related to the goal "Prepare city's adaptation to climate change" could benefit from a closest relationship between the Strategy and the 10-year program of actions designed by the River Basin Authority to guarantee the safety of Rome from floods, landslides and sinkholes (River Basin District Authority 2018). Unfortunately, this program is not even mentioned in the Strategy, probably due to its recent adoption. Other specific actions are strongly linked to sectoral plans, such as the Sustainable Urban Mobility Plan (SUMP). Finally, it is worth noting that the Resilience Strategy does not explicitly refer to the 2008 General Urban Masterplan, which was updated in 2016, introducing issues in line with the climate-related ones defined by the strategy, such as the creation of urban ecological networks (Fig. 9).

Athens' Resilience Strategy also draws upon other local, regional, national and international strategic documents and it seems to be aware of the lack of communication among the different municipal departments and public bodies and, consequently, of the lack of coherence among policies and plans. Moreover, it clearly acknowledges the citizens' need for more information and improved mechanisms allowing their engagement in decision-making 
Table 1 The whole set of actions outlined by the Rome Resilience Strategy and those addressed to counterbalance climate change

Pillars, goals and actions

Climate response

Pillar I: An efficient city at the service of citizens

Priority action 1: Create an operation and management center

Priority action 2: Establish a Resilience Office

Goal A: Make the administration of the city more efficient, transparent and participatory; and ensure the monitoring of procedures

I.A.1. Link the budget commitments to the 3-year annual programming of the Departments'activities

I.A.2. Reorganize the running of Departments and encourage synergies with other institutions

I.A.3. Create a unique communications interface between private citizens and the Public Administration with the help of new technologies

I.A.4. Establish guidelines to optimize the planning, construction and management of projects

Goal B: Incentivize centralized governance actions

I.B.1. Complete the implementation of the 'Rome' laws required to ensure greater governance autonomy of the region (e.g. archaeological parks, rivers, etc.)

I.B.2. Create a unique geographical database that may be updated and shared

I.B.3. Establish a Geological Survey of Rome to ensure an integrated governance of soil and subsoil

Goal C: Implement the Smart City plans

I.C.1. Introduce guidelines for updating the Open Data platform

I.C.2. Upgrading the public Wi-Fi network and coverage

I.C.3. Construct a Smart Grid

Pillar II: A dynamic, strong and unique city

Priority action 1: Govern the relaunch of the River Tiber by implementing projects coordinated by the Special Office for the Tiber

Priority action 2: Evaluation of the resilience potential of the regeneration of Ostiense Marconi district

Priority action 3: Change the perception, use and promotion of the archaeological and cultural heritage sites in Rome for citizens' everyday life

Goal A: Promote the cultural life of the city

II.A.1. Reorganize the management of the cultural sector

II.A.2. Support stakeholders in the contemporary cultural sector in the dissemination of the cultural offer

II.A.3. Organize seasonal programs of cultural events throughout the city

II.A.4. Assign a new role to public libraries by organizing innovative socio-cultural programs for the local communities

II.A.5. Start the application to list Ostia Antica as a UNESCO World Heritage Site

II.A.6. Fashion Relaunch Plan of Rome

Goal B: Promote urban regeneration

II.B.1. Activate Fabbrica Roma (Rome Factory), a regeneration plan for abandoned public buildings

II.B.2. Upgrade the Building Regulations according to new housing and working needs

II.B.3. Regenerate the Tiburtina Stations and Pietralata areas

$-$

$$
-
$$$$
-
$$$$
-
$$

Mitigation

Adaptation

$-$

$-$ $-$ Mitigation Mitigation cable cars, etc.)

II.B.5. Establish incentives to facilitate the transfer of know-how between small-medium businesses, start-ups, institutions and research centers

Goal C: Promote the landscape and natural heritage in the urban environment

II.C.1. Restore and/or reorganize the use of and access to the Roman coast by implementing the Utilization Plan for Rome's Coastline

II.C.2. Implement the management reorganization of parks and historic villas by establishing a Curator who would also be responsible for planning the fundraising processes

Goal D: Encourage the farming tradition of the city

II.D.1. Relaunch farming companies managed by the Municipality

II.D.2. Develop new markets for farmers to support the direct sale of produce and products to consumers

II.D.3. Increase food forests and urban vegetable gardens

Adaptation

Goal E: Improve the attractiveness and safety of Rome

II.E.1. Create tourist facilities to promote youth and student tourism 
Table 1 (continued)

\begin{tabular}{|c|c|}
\hline Pillars, goals and actions & Climate response \\
\hline $\begin{array}{l}\text { II.E.2. Plan activities to promote the attraction of urban areas by increasing the number of cycling tracks, environmental } \\
\text { islands and use of the public transport system }\end{array}$ & Mitigation \\
\hline $\begin{array}{l}\text { II.E.3. Regulate businesses in the historic center in order to protect the quality of products and craftsmanship so as to } \\
\text { preserve the identity and the propriety of the historic center }\end{array}$ & - \\
\hline \multicolumn{2}{|l|}{ Goal F: Ensure the safety of the public and private heritage sites in the city } \\
\hline II.F.1. Protect infrastructure, public buildings, and schools & Adaptation \\
\hline \multicolumn{2}{|l|}{ Goal G: Prepare the city's adaptation to climate change } \\
\hline II.G.1. Create green and blue infrastructure to reduce urban heat islands & Adaptation \\
\hline II.G.2. Assess the impacts of climate change and raise awareness among citizens & Adaptation \\
\hline II.G.3. Create infrastructure and pilot projects to reduce the risk of flooding & Adaptation \\
\hline \multicolumn{2}{|l|}{ Pillar III: An open inclusive and supportive city } \\
\hline $\begin{array}{l}\text { Priority action 1: Implement a program to encourage everyone into sports to enable social integration of diverse communi- } \\
\text { ties }\end{array}$ & - \\
\hline $\begin{array}{l}\text { Priority action 2: Implement the new social integration program for asylum seekers and other people covered by interna- } \\
\text { tional protection }\end{array}$ & - \\
\hline \multicolumn{2}{|l|}{ Goal A: Promote a hospitable city that respects diversity } \\
\hline III.A.1. Implement a program to strengthen and extend the support network for vulnerable communities & Adaptation \\
\hline $\begin{array}{l}\text { III.A.2. Establish assessment criteria to assign public spaces under concession to NGOs, associations and organizations that } \\
\text { promote social inclusion, education and sustainability }\end{array}$ & - \\
\hline III.A.3. Finalize Public Housing Development Programs and develop new energy-efficient social housing & Mitigation \\
\hline \multicolumn{2}{|l|}{ Goal B: Promote the cultural growth of the vulnerable population } \\
\hline III.B.1. Introduce projects for the inclusion of children in the cultural life of the city in collaboration with other institutions & - \\
\hline $\begin{array}{l}\text { III.B.2. Implement the new intervention policies for unaccompanied foreign minors to facilitate opportunities of growth } \\
\text { and integration }\end{array}$ & - \\
\hline \multicolumn{2}{|l|}{ Pillar IV: A city that protects and enhances its natural resources } \\
\hline Priority action 1: Renew the public vehicle fleet and introduce eco-sustainable buses & Mitigation \\
\hline Priority action 2: Optimize separate waste collection of post-consumer materials & Mitigation \\
\hline \multicolumn{2}{|l|}{ Goal A: Protect the ecological system and restore the value of the water resources } \\
\hline $\begin{array}{l}\text { IV.A.1. Implement sustainable urban forestry principles to protect biodiversity, enhance and protect parks and nature } \\
\text { reserves }\end{array}$ & Mitigation \& adaptation \\
\hline IV.A.2. Protect and enhance local water resources & Adaptation \\
\hline \multicolumn{2}{|l|}{ Goal B: Promote the use of renewable energy sources } \\
\hline IV.B.1. Incentivize the use of renewable resources & Mitigation \\
\hline IV.B.2. Introduce incentives to secure the safety and energy efficiency of private real estate property & Mitigation \\
\hline IV.B.3. Review the green credential and safety of the public structures & Mitigation \\
\hline \multicolumn{2}{|l|}{ Goal C: Create sustainable mobility and introduce solutions to reduce pollution and greenhouse gas emissions } \\
\hline IV.C.1. Develop an efficient and economic transport model for people and goods & Mitigation \\
\hline IV.C.2. Develop sustainable electric mobility plan & Mitigation \\
\hline IV.C.3. Test new technologies for decreasing emissions into the atmosphere & Mitigation \\
\hline IV.C.4. Develop the pedestrian and cycle network and sharing transport schemes & Mitigation \\
\hline \multicolumn{2}{|l|}{ Goal D: Promote a zero-waste circular economy } \\
\hline IV.D.1. Open centers for the direct processing and reuse of post-consumer materials & Mitigation \\
\hline IV.D.2. Develop sustainable waste plants & Mitigation \\
\hline
\end{tabular}

processes. Hence, the Strategy aims at creating information platforms for municipal departments, stakeholders and communities, promoting partnerships with national and international networks and favoring linkages with other plans, programs and initiatives. These endeavors make data and services available to everyone, ensure the comprehensive dissemination of relevant information and raise awareness about resilience issues.

Regarding the interdependencies with other plans (Fig. 10), City's Plan of Integrated Urban Intervention and the Integrated Territorial Investments Actions are two of the main documents underpinning the Resilience Strategy. City's 


\section{ATHENS 41344 \\ pillars goals actions}

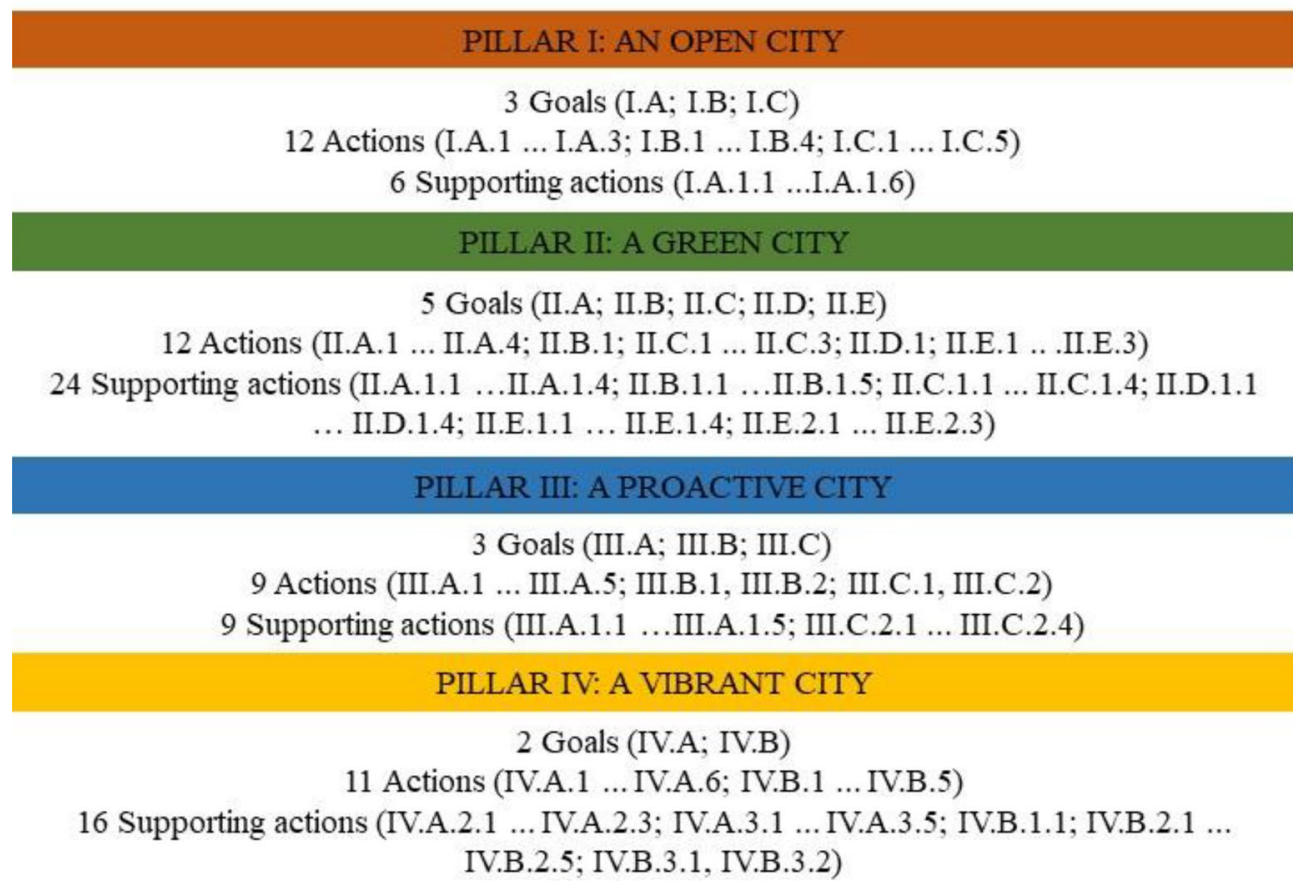

Fig. 8 The structure of the Athens Resilience Strategy

Sustainable Urban Development Plan is another key document along with the New Regulatory Plan of Athens-Attica 2021. The Strategy also takes into account the Urban Agenda for the EU, the New Urban Agenda-Habitat III and the UN Sustainable Development Goals. Moreover, many actions of the Athens' Climate Change Adaptation and Mitigation Plan are incorporated in the Resilience Strategy. This Plan is the outcome of the collaboration between ORS and the C40 Advisor for Athens (C40 Cities Climate Leadership Group) and includes two parts, respectively focused on mitigation and adaptation, outlining specific actions aimed at improving quality of life, mostly in respect to increasing temperatures, flash floods and poor air quality. Other actions of the Strategy are linked with urban, regional and national plans for sustainable mobility, waste management system, energy saving programs and economic strategic plans, the migrant integration action plan, the public space co-development framework, the crisis preparedness and management plans as well as the sustainable food policy plan.

It is worth mentioning that Athens entered the Smart Mature Resilience (SMR) project in November 2017, which responds to the need for enhanced resilience in European cities. Athens is one of the Tier 3 cities, meaning that is one of the 'engaged' cities that receives training in the use of the developed tools (Grimes 2018). The engagement of the city into this project could represent a further opportunity to strengthen awareness, capabilities and skills within the different sectors of the public administration and to empower, in so doing, local institutions, making the latter more autonomous in respect to the leading role hitherto assumed by the Rockefeller Foundation.

Finally, it is worth mentioning that some of the actions included in the Athens Strategy served as a model for other cities, such the open-schools initiative, the EXTREMA Europe phone application and the Lycabettus Hill Program. ${ }^{13}$

\footnotetext{
${ }^{13}$ The EXTREMA Europe phone application has been developed by the National Observatory of Athens (NoA) in the framework of the European project TREASURE. Is part of the Supporting Action III. A.1.5 [III. Proactive City, A.1.5 Collaboration with National Observatory of Athens (NoA)]. The Lycabettus Hill Programis part of the Action II. A.2 (II. A Green City, A.2 Major green areas managing authority).
} 
Table 2 The whole set of actions outlined by the Athens Resilience Strategy and the actions addressed to counterbalance climate change

Pillars, goals and actions

Climate response

I. An Open City

Goal A. Become more transparent and accountable

A.1 Open data

A.2 Communication campaigns

A.3 Major public events impact assessment

Goal B. Enhance and streamline the city's processes

B.1 Digital agenda

B.2. Smart operational center

B.3 Health \& social service centers

B.4 Map of the public realm

Goal C. Foster collaboration and engagement

C.1 Thematic stakeholder platforms

C.2 synAthina platform

C.3 University and City Synergies

C.4 Athens Partnership Fund

C.5 Athens Culture Net

II. A Green City

Goal A. Integrate natural systems into the urban fabric

A.1 Climate Change adaptation action plan

Adaptation

A.2 Major green areas managing authority

Adaptation

A.3 Triple green development project (Mega Resilience Project)

Adaptation

A.4 Elaionas: a resilient district (Mega Resilience Project)

Mitigation \& adaptation

Goal B. Make our city cleaner

B.1 Waste management action plan

Mitigation

Goal C. Promote sustainable mobility and co-create public spaces

C.1 Sustainable mobility roadmap

C.2 Public space rejuvenation initiative

C.3 Public space co-development framework

Goal D. Foster sustainable food systems

D.1 Sustainable food policy plan

Mitigation

Goal E. Establish sustainable and equitable energy system

E.1 Climate Change mitigation action plan

Mitigation

E.2 Energy poverty mitigation roadmap

Mitigation

E.3 Renewable energy cooperatives

Mitigation

III. A proactive city

Goal A. Enhance planning in the face of serious challenges

A.1 Crisis preparedness and management plans Adaptation

A.2 Scenario-based issues and methods

A.3 Metropolitan Authority and other legislative and policy making reforms

Adaptation

A.4 Detailed resilience studies

Adaptation

A.5 Old building retirement

Mitigation \& adaptation

Goal B. Empower the municipal workforce and elected officials as well as the voice of the local community

B.1 Municipal neighborhood network

Adaptation

B.2 Municipal capacity building

Mitigation

Goal C. Engage with our neighborhoods

C.1 Schools open to the neighborhood

C.2 Migration integration action plan 
Table 2 (continued)

\begin{tabular}{lc}
\hline Pillars, goals and actions & Climate response \\
\hline IV. A vibrant city & - \\
Goal A. Enhance the City's identity and promote new types of belonging & - \\
A.1 Athens ID & - \\
A.2 Creative economy strategic plan & Adaptation \\
A.3 Holistic city brand & - \\
A.4 Green and cultural urban corridors & Mitigation \&adaptation \\
A.5 Sustainable municipal Real-estate management & - \\
A.6 City center development project & - \\
Goal B. Maximize existing City assets and support employment & Adaptation \\
B.1 Vacant buildings: crucial urban resource & - \\
B.2 Employment action framework & Adaptation \\
B.3 Social housing program & \\
B.4 Old train stations refurbishment & \\
B.5 Expropriation and greening of abandoned lots in Athens & \\
\hline
\end{tabular}

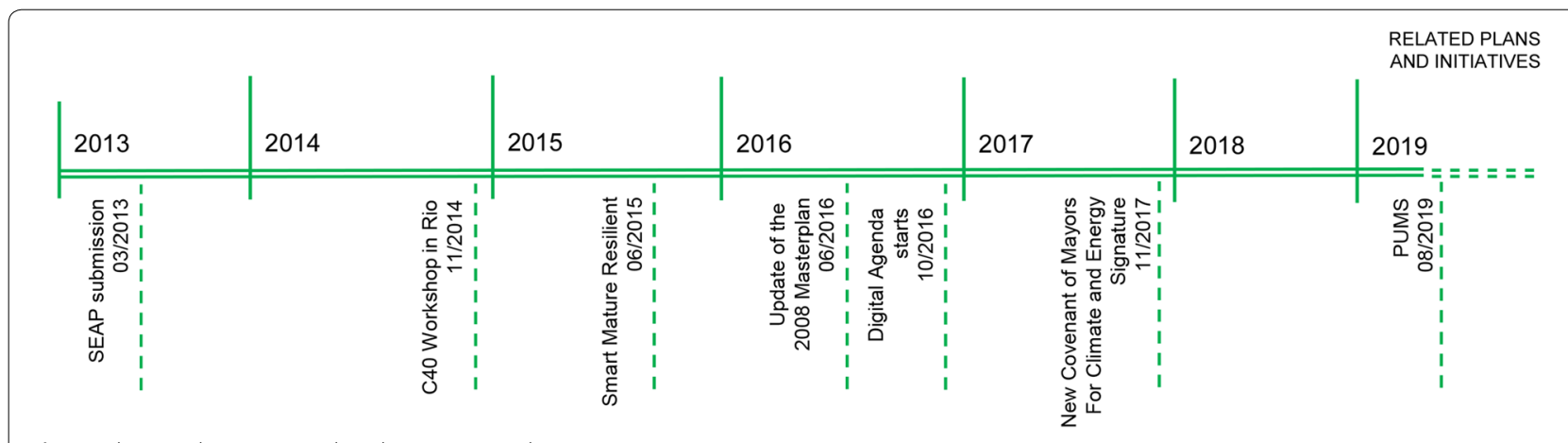

Fig. 9 Plans and initiatives related to Rome Resilience Strategy

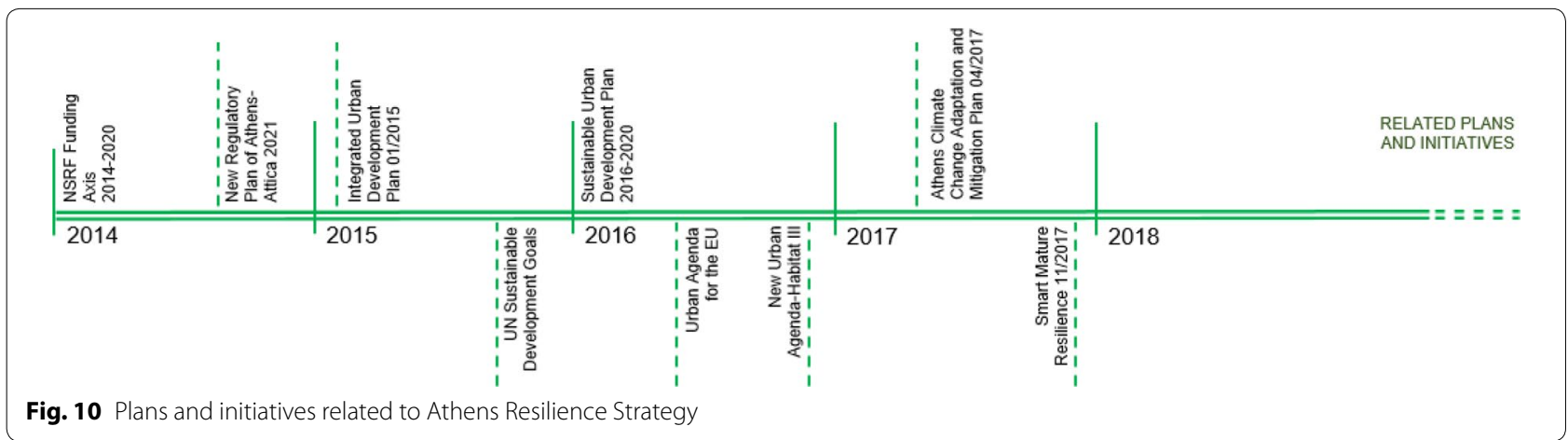

However, it is worth outlining that, despite the attention paid to creating links with other plans and initiatives, in both the delivered Resilience Strategies the mutual influences among the foreseen actions (both the new ones and those already planned) are not explicitly analyzed. This is a significant weakness for Strategies aimed at framing different actions into a common and shared vision since they do not allow recognizing for example, the potential impacts of the large neighborhoods' redevelopment projects included in both strategies on existing social inequalities. These projects, if not adequately designed and implemented, could significantly increase social inequality while improving environmental quality: therefore, despite the premises of the 100RC, the 
examined Resilience Strategies seem inadequate to provide an effectively integrated approach to the multiple challenges that contemporary cities are called to face and, in particular, to the two sides of the new urban question.

\section{Discussion and conclusions}

Six years after the launch of the 100RC Initiative, in July 2019, the Rockefeller Foundation has deemed to be concluded this program, launching new ones for supporting cities' activity in this field: the Resilient City Catalyst ${ }^{14}$ and the new Global Resilient Cities Network (GRCN), ${ }^{15}$ both of them built on the legacy of the 100RC. Reflecting on this Initiative, and above all on how it has been unfolded in Rome and Athens, we aim to contribute to the emerging debate on both the legacy that this Initiative left to cities all over the world, in terms of new approaches to urban resilience as well as of new tools to analyze, evaluate and improve it, and on the doubts and questions it raise.

In respect to the legacy, it is worth underlining that local governments have been provided with useful tools for understanding, assessing, and improving their capacity to cope with different stresses and shocks: CFR and CRI allow cities establishing a baseline against which they can define and prioritize goals and actions and monitor their progresses. All the involved cities had the opportunity, thanks to these tools as well as to the external financial and organizational support, to recognize both the main shocks and stresses and the main challenges to be faced and to carry out a resilience strategy aimed at addressing them.

Moreover, all the resilience strategies have been developed through participatory decision-making processes based on a cross-sectoral cooperation among different institutions as well as on the engagement of multiple stakeholders, including citizens, which allowed increasing decision makers' and communities' awareness on resilience issues. The experimentation of these new forms of governance, innovative in some cities, such as the considered case studies, represented an opportunity to progress towards a systemic-oriented knowledge of urban phenomena (Williams and Hardison 2013), which is considered a prerequisite for developing cross-sectoral strategies capable of overcoming the still prevailing "silo" approach to urban policies (Proust et al. 2012; Galderisi 2016).

Finally, the involvement into a world network allowed cities and communities recognizing common challenges, learning from each other, and sharing good practices

\footnotetext{
${ }^{14}$ https://www.rcc.city.

15 https://www.rockpa.org/project/global-resilient-cities-network/.
}

(The Rockefeller Foundation 2019). As remarked by Elmqvist et al. (2019) the city network created by the 100RC Initiative can be considered a remarkable example of how "knowledge co-production amongst cities and city-networks may bring about new urban solutions applicable across scales and across geographies for urban resilience and urban sustainability".

Despite its positive legacy, the 100RC Initiative raises also some doubts and questions. First of all, most of the Resilience Strategies carried out by the involved cities, including the analyzed case studies, refer to the municipal boundaries of the cities. However, cities are nowadays widely interpreted as open systems that should be analyzed and regulated through multi-scale approaches, capable of taking into account the multiple relationships linking both the different neighborhoods within the city and the city itself to its metropolitan or regional context. Hence, it would be important to deeply analyze the potential, positive or negative, implications that improving resilience at a given spatial scale might have at different scales, wider or narrower in respect to the considered one, such as a region or a single neighborhood (Sapountzaki 2007; Elmqvist et al. 2019). Unfortunately, at least in the examined case studies, cross-scale analyses aimed at evaluating the potential implications of the foreseen actions at different scales are missing.

Moreover, the two case studies highlight the lack of an effective cross-sectoral approach. Despite the emphasis put by the Initiative on the cross-sectoral cooperation among different sectors of the public administration, it is worth noting that in both cities, no evaluation of the cross-sectoral impacts of the foreseen actions, neither in itinere nor ex post, has been carried out. For example, the potential impacts on the already relevant social inequalities of the large neighborhoods' redevelopment projects, included in both strategies and addressed to improve environmental quality, should be adequately addressed, since Resilience Strategies should improve cities' capacities to cope with the multiple and often interconnected challenges that contemporary cities have to face.

Another key point to be discussed refers to the effectiveness of the stakeholders' engagement processes. Despite the large emphasis put by this Initiative on the active participation of local stakeholders, which represents a critical factor for any effective and inclusive resilience building process (Borquez et al. 2016; Satorras et al. 2020), the limited timeline for delivering the Resilience Strategies raises some reasonable doubts on the possibility of a real involvement of local stakeholders, especially for cities that lack a consolidated tradition of citizens' participation in decision-making processes, as the selected case studies. The active participation of diverse urban stakeholders, including scientists, 
politicians, business, media, and citizens in all the phases of the process is, in fact, generally time-consuming, especially in contexts that starts from scratch. Therefore, it seems to be not fully compatible with the shortterm horizon assigned to the delivering of the Resilience Strategies. Furthermore, both case studies lack a detailed description of the adopted criteria for selecting and prioritizing citizens' groups to be involved.

Focusing in detail on the two case studies, it is worth reminding that they show numerous similarities in terms of shocks and stresses to be faced and that, in both cities, climate-related impacts are recognized as a major challenge exacerbated by a vulnerable built environment, characterized by high population densities, inadequate infrastructures, lack of public green areas as well as of effective maintenance policies of the building stock. Even though the economic crisis and that induced by the increasing flows of migrants and refugees are mentioned as chronic stresses in both cities, their relevance in Athens is significantly higher, while the lack of integrated and participatory governance represents a very sensitive issue in both cases.

In both cities, the involvement in the 100RC Initiative has surely represented an opportunity to address some critical issues related to different urban dimensions (society, economy, environment and governance), to develop a shared vision for future development, and to systematize into a common frame new and on-going actions already included in different tools (e.g. climate plans, urban regeneration projects, etc.). Moreover, the engagement in the 100RC Initiative contributed in both cases to improve decision-makers' and citizens' awareness about the existing and emerging challenges they have to cope with and to test new governance models, based on more participatory and cross-sectoral approaches to decision making processes.

Still, both cities have fully grasped the opportunity offered by this Initiative, also due to the limited timespan for delivering the Resilience Strategies, to systematize already existing initiatives and actions, bringing them under a common umbrella (Fitzgibbons and Mitchell 2019).

In Rome, the resilience building process allowed framing the on-going actions into an overall strategy, based on a shared vision for city's development. Nevertheless, the discontinuities that characterized the resilience building process, largely due to the change of its leading actors, contributed to slow down the delivering of the Resilience Strategy.

It is worth emphasizing that the lack of a stable political leadership, as in the case of Rome, may also affect the following phase of the resilience building process, that is the implementation phase, when the organizational and technical support provided by the Rockefeller Foundation and by the external experts, such as ARUP, is no longer available and the process is completely entrusted to local actors.

Furthermore, both case studies highlight the sensitiveness of the resilience building process to the background of the selected cities in terms of available knowledge, previous involvement in international networks, leading capacities in promoting urban policies. Available scientific literature clearly underlines that while cities characterized by a long-term leadership in promoting urban policies on sustainability and climate change found in their engagement in the 100RC Initiative an opportunity to broaden the scope of their policies towards a sustainable and resilient urban development (Spaans and Waterhout 2016), cities characterized by a structural weakness of urban policies, as the examined ones or some cities from the Global South (Sutherland et al. 2019), encountered significant difficulties along the path aimed at delivering the Resilience Strategy due, for example, to the lack of adequate knowledge, which resulted into a longer time for developing a deep understanding of the city's context, or to the low propensity for collaboration between different sectors of public administration.

In the case of Athens, the most significant legacy of its engagement in the 100RC Initiative is the institutionalization of the role of the CRO and the change, hopefully lasting, in planning processes. Traditionally the Greek planning system has been highly centralized, focused on the regulatory aspects of planning, with slow and long-term processes and relatively weak institutional structures regarding implementation and social acceptance along with inadequate data which are essential for addressing climate change (Yiannakou and Salata 2017; Yiannakou 2020). In this context, the Resilience Strategy represented a significant opportunity to introduce and test more collaborative (including local and international partners) and participatory decision-making processes.

Finally, it is worth pointing out that, 2 years after the release of both the Resilience Strategies, the selected case studies lack structured monitoring reports, highlighting the progresses actually made and the way still to go. In Athens, an assessment of the 3 years of ORS was performed by the municipality in May 2018. According to this assessment, 26 actions out of the 44 included in the Strategy were being implemented at that moment. Most of them are part of the Pillars I \& II, with the majority of the latter being characterized in the Strategy as new actions. However, this information has been provided by email by the Resilience and Sustainability Department of the City of Athens, while in the case of Rome the requests for information remained unanswered. 
The failure to establish a structured and continuous monitoring process represents a significant weakness: according to an 'evolutionary' approach to resilience (Davoudi et al. 2012), in fact, the resilience building process should be intended as an ongoing process based on learning. Along this process, the 100RC program should represents only one a step and also the delivered Strategy should be a living document, to be continuously updated and fine-tuned as planned actions are implemented (Berkowitz and Kramer 2018).

\begin{abstract}
Abbreviations
100 RC: 100 Resilient Cities; CRF: City Resilience Framework; CRO: Chief Resilience Officer; ESTIA: Emergency Support to Integration and Accommodation; GHG: Greenhouse gas; GRCN: Global Resilient Cities Network; IOM: International Organization for Migration; LEAC: Land and Ecosystem Accounts; LST: Land Surface Temperature; ORS: Office of Resilience and Sustainability; PRA: Preliminary Resilience Assessment; RSC: Resilience Steering Committee; SECAP: Sustainable Energy and Climate Action Plan; SMR: Smart Mature Resilience; SUMP: Sustainable Urban Mobility Plan; UHI: Urban Heat Island; UNISDR: United Nations International Strategy for Disaster Reduction.
\end{abstract}

\section{Acknowledgements}

Not applicable.

\section{Authors' contributions}

This paper should be considered a result of the common work of the authors under the supervision of the first author AG, who conceived and guided the work. AG wrote "Enhancing Cities'Resilience: why and how","The 100 RC Initiative", and "Discussion and Conclusions" sections; GL and KDS wrote "Cases description: Rome and Athens, two paradigmatic examples of the 'new urban question", "Rome and Athens: the resilience building process", and "Rome and Athens Resilience Strategies: the focus on climate issues" sections. Figures are elaborated by GL. All authors read and approved the final manuscript.

\section{Funding}

The article processing charge for the publication in this open access journal was funded by the "V:ALERE 2019 program" of the University of Campania Luigi Vanvitelli (Italy).

\section{Availability of data and materials}

Not applicable.

\section{Competing interests}

The authors declare that they have no competing interests.

\section{Author details}

${ }^{1}$ Department of Architecture and Industrial Design, University of Campania Luigi Vanvitelli, Aversa, Italy. ${ }^{2}$ School of Spatial Planning and Development, Aristotle University of Thessaloniki (AUTh), Thessaloniki, Greece.

Received: 20 April 2020 Accepted: 17 October 2020

Published online: 02 November 2020

\section{References}

Albrechts L, Barbanente A, Monno V (2020) Practicing transformative planning: the territory-landscape plan as a catalyst for change. City Territ Arch 7(1):2-13. https://doi.org/10.1186/s40410-019-0111-2

Alexander DE (2013) Resilience and disaster risk reduction: an etymological journey. Nat Hazards Earth Syst Sci 13:2707. https://doi.org/10.5194/ nhess-13-2707-2013

Beck U (2010) Remapping social inequalities in an age of climate change: for a cosmopolitan renewal of sociology. Global Netw 10(2):165-181. https:// doi.org/10.1111/j.1471-0374.2010.00281.x
Béné C, Wood RG, Newsham A, Davies M (2012) Resilience: New Utopia or New Tyranny reflection about the potentials and limits of the concept of Resilience in relation to vulnerability reduction programmes. IDS Work Papers 405:1-61. https://doi.org/10.1111/j.2040-0209.2012.00405.x

Berkowitz M, Kramer AM (2018) Helping cities drive transformation: the 100 Resilient Cities Initiative, Field Actions Science Reports [Online], Special Issue 18. http://journals.openedition.org/factsreports/4885. Accessed 12 Sep 2020

Borquez R, Aldunce P, Adler C (2016) Resilience to climate change: from theory to practice through co-production of knowledge in Chile. Sustain Sci 12:163-176. https://doi.org/10.1007/s11625-016-0400-6

Brenner N, Schmid C (2015) Towards a new epistemology of the urban? City 19(2-3):151-182. https://doi.org/10.1080/13604813.2015.1014712

Chalkias C, Delladetsimas PM, Sapountzaki K (2015) Natural hazards and climate change risks in Athens. In: Maloutas T, Spirellis S (eds) Athens social atlas. https://www.athenssocialatlas.gr/en/article/natural-hazar ds-and-climate-change/. Accessed 5 Mar 2020

Coppola A (2016) Mobilità delle politiche e inerzia del locale: il caso di Roma Resiliente. Working papers Urban@it 2: 2-12. ISSN 2465-2059

Coppola A (2018) Problemi pubblici emergenti fra scienza ed azione pubblica La sfida (rimandata?) delle governance e delle politiche della complessità a Roma. In: Coppola A, Punziano G (eds) Roma in Transizione Governo, strategie, metabolismi e quadri di vita di una metropoli. Planum Publisher, Roma

Croese S, Green C, Morgan G (2020) Localizing the sustainable development goals through the lens of urban Resilience: lessons and learnings from 100 Resilient Cities and Cape Town. Sustainability 12(2):550. https://doi. org/10.3390/su12020550

Davoudi S, Shaw K, Haider JL et al (2012) Resilience: a Bridging Concept or a Dead End? "Reframing" Resilience: Challenges for Planning Theory and Practice Interacting Traps: Resilience Assessment of a Pasture Management System in Northern Afghanistan Urban Resilience: What Does it Mean in Planning Practice? Resilience as a Useful Concept for Climate Change Adaptation? The Politics of Resilience for Planning: A Cautionary Note. Plan Theor Pract 13(2):299-333. https://doi.org/10.1080/14649 357.2012.677124

Elmqvist T, Andersson E, Frantzeskaki N, McPhearson T, Olsson P et al (2019) Sustainability and resilience for transformation in the urban century. Nat Sustain 2:267-273. https://doi.org/10.1038/s41893-019-0250-1

Fitzgibbons J, Mitchell CL (2019) Just urban futures? Exploring equity in "100 Resilient Cities". World Dev 122:648-659. https://doi.org/10.1016/j.world dev.2019.06.021

Gabellini P (2018) Le mutazioni dell'urbanistica. Principi, tecniche, competenze. Carocci editore, Roma

Galderisi A (2016) The nexus approach to disaster risk reduction, climate adaptation and ecosystem management: new paths for a sustainable and resilient urban development. In: Colucci A, Magoni F, Menoni S (eds) Peri-urban areas and food-energy-water nexus. sustainability and resilience strategies in the age of climate change. Springer, Cham. https ://doi.org/10.1007/978-3-319-41022-7_2

Galderisi A (2018) The Resilient City metaphor to enhance Cities'capabilities to tackle complexities and uncertainties arising from current and future climate scenarios. In: Galderisi A, Colucci A (eds) Smart, Resilient and transition cities emerging approaches and tools for a climate-sensitive urban development. Elsevier, Amsterdam

Gotham, K. and Campanella, R. (2010) Toward a Research Agenda on Transformative Resilience: Challenges and Opportunities for Post-Trauma Urban Ecosystems. Critical Planning Summer. http://richcampanella.com/ wp-content/uploads/2020/02/article_Gotham\%20Campanella\%20Cri tical\%20Planning-resilience\%20of\%20New\%20Orleans.pdf Accessed 12 Sep 2020

Grimes C (2018) Smart Mature Resilience Stakeholder. Workshop Report ICLEI -Local Governments for Sustainability.https://ec.europa.eu/research/parti cipants/documents/downloadPublic?documentlds $=080166 \mathrm{e} 5 \mathrm{~b} 6 \mathrm{cff} 9 \mathrm{~b}$ b\&appld=PPGMS. Accessed 09 Apr 2020

Hallegatte S, Rozenberg J (2017) Climate change through a poverty lens. Nature Climate Change 7:250-256. https://doi.org/10.1038/nclimate3253

Holling CS (1996) Engineering resilience versus Ecological resilience. In: Schulze P (ed) Engineering with ecological constrains. National Academy, Washington 
International Organization for Migration (IOM) Office in Greece (2020) Improving the Greek reception system through site management support and targeted interventions in long-term accommodation sites. Site Factsheet January 2020. https://greece.iom.int/sites/default/files/FINAL_21_2min_0.pdf. Accessed 10 Mar 2020

Kartalis K, Oikonomou D, Kokkosis H, Santamouris M, Agathaggelidis E, Polydoros A (2017) The Impact of climate change on the Greek economy. Athens: diaNEOsis. https://www.dianeosis.org/en/2017/08/impact-clima te-change-greek-economy/. Accessed 17 Mar 2020

Maloutas T, Karadimitriou N (2001) Vertical social differentiation in Athens: alternative or complement to urban segregation? Int J Urban Reg Res 25(4):699-716. https://doi.org/10.1111/1468-242700340

Maloutas T, Spirellis SN (2015) Vertical social segregation in Athenian apartment buildings. In: Maloutas T, Spirellis S (eds) Athens social atlas. https:// www.athenssocialatlas.gr/en/article/vertical-segregation/. Accessed 30 May 2019

Maloutas T, Spirellis SN (2019) Inequality and segregation in Athens: Maps and data. In Maloutas T, Spirellis S (eds) Athens social atlas. https://www.athen ssocialatlas.gr/en/article/inequality-and-segregation-in-athens/\#1.4\%20 Ethic\%20groups. Accessed 5 Mar 2020

Markkanen S, Anger-Kraavi A (2019) Social impacts of climate change mitigation policies and their implications for inequality. Clim Policy 19(7):827844. https://doi.org/10.1080/14693062.2019.1596873

Monno V, Serreli S (2020) Cities and migration: generative urban policies through contextual vulnerability. City Territ Archit 7(6):2-17. https://doi. org/10.1186/s40410-020-00114-X

Morabito M, Crisci A, Gioli B, Gualtieri G, Toscano P, Di Stefano V et al (2015) Urban-hazard risk analysis: mapping of heat-related risks in the elderly in major Italian Cities. PLoS ONE 10(5):e0127277. https://doi.org/10.1371/ journalpone0127277

Munafò M (2019a) Consumo di suolo, dinamiche territoriali e servizi ecosistemici, ed. 2019. Report SNPA 08/19: 62-78. ISBN 978-88-448-0964-5

Munafò M (2019b) Consumo di suolo, dinamiche territoriali e servizi ecosistemici, ed. 2019. Report SNPA 08/19: 149-155. ISBN 978-88-448-0964-5

Munafò, M. (a cura di), 2020. Consumo di suolo, dinamiche territoriali e servizi ecosistemici. Edizione 2020. Report SNPA 15/2020

Munafò M, Polverini R (2018) II consumo di suolo di Roma Capitale. Roma Capitale-ISPRA. https://www.comune.roma.it/web-resources/cms/ documents/Consumo_suolo_1_02_19.pdf. Accessed 30 May 2019

Munafò M, Polverini R (2019) II consumo di suolo di Roma Capitale. Analisi della copertura di suolo nel territorio del Comune di Roma. Rapporto 2019. Progetto del Servizio Civile Nazionale della U O Statistica - Open Data di Roma Capitale in collaborazione con I'ISPRA - Dipartimento per il Servizio Geologico d'Italia

Municipality of Rome-General Accounting (2017) I principali indicatori di fabbisogno per Municipio a Roma Capitale. Anno 2015. Ragioneria Generale. I Direzione "Sistemi informativi di pianificazione e controllo finanziario". UO Statistica Roma. https://www.comune.roma.it/web-resources/cms/ documents/Indicatori_fabbisogno_2015.pdf. Accessed 03 Mar 2020

Proust K, Newell B, Brown H et al (2012) Human health and climate change: leverage points for adaptation in urban environments. Int J Environ Res Public Health 9(2012):2134-2158. https://doi.org/10.3390/ijerph9062134

Resilient Athens (2017) Athens Resilience Strategy for 2030: Redefining the City. Athens: Resilient Athens \& City of Athens. https://www.100resilie ntcities.org/strategies/. Accessed 30 May 2019

Resilient Athens-Athens Development and Destination Management Agency (ADDMA SA) \& City of Athens (2016) Athens: Emergent Metropolis. Preliminary Resilience Assessment. Athens: Resilient Athens. ADDMA SA $\&$ City of Athens

Resilient Rome (2016) Valutazione Preliminare di Resilienza. http://www.urban istica.comune.roma.it/roma-resiliente/1243-valutazione-preliminare-resil ienza.html. Accessed 09 Apr 2020

Resilient Rome (2018) Rome Resilience Strategy. City Strategies 100 Resilient Cities. https://www.100resilientcities.org/strategies/. Accessed 30 Apr 2019

River Basin District Authority (2018) II Piano Roma Sicura. Primo rapporto su rischio alluvioni, frane, cavità del sottosuolo e acque sotterranee. River Basin District Authority. Italia Sicura, DPC, ISPRA. http://www.ispra mbiente.gov.it/files2018/pubblicazioni/rapporti/piano_roma_sicura.pdf. Accessed 23 May 2019
Sapountzaki K (2007) Social resilience to environmental risks: a mechanism of vulnerability transfer? Manag Environ Qual 18(3):274-297. https://doi. org/10.1108/14777830710731743

Satorras M, Ruiz-Mallén I, Monterde A, March H (2020) Co-production of urban climate planning: insights from the Barcelona Climate Plan. Cities. https:// doi.org/10.1016/j.cities.2020.102887

Secchi B (2013) La città dei ricchi e la città dei poveri. Laterza eds, Roma

Shaw K (2012) "Reframing" Resilience: challenges for Planning Theory and Practice. Plan Theor Pract 13(2):308-312. https://doi.org/10.1080/14649 357.2012.677124

Spaans M, Waterhout B (2016) Building up resilience in cities worldwideRotterdam as participant in the 100 Resilient Cities Programme. Cities 61:109-116. https://doi.org/10.1016/j.cities.2016.05.011

Sutherland C, Roberts D, Douwes J (2019) Constructing resilience at three scales: The 100 Resilient Cities programme, Durban's resilience journey and water resilience in the Palmiet Catchment. Human Geogr 12(1):3349. https://doi.org/10.1177/194277861901200103

The Rockefeller Foundation (2019) Resilient Cities, Resilient Lives learning from the 100RC Network July 2019

The Rockefeller Foundation \& Arup (2015) City Resilience Framework. https ://www.rockefellerfoundation.org/wp-content/uploads/City-Resilience -Framework-2015.pdf. Accessed 13 Sept 2020

The Rockefeller Foundation \& Arup (2016) City Resilience Index: Understanding and measuring city resilience https://www.rockefellerfoundationorg/ report/city-resilience-index/. Accessed 13 Sept 2020

Tocci W (2015) Non si piange su una città coloniale. Note sulla politica romana. GoWare, Firenze

UN (2015) Transforming Our World: The 2030 Agenda for Sustainable Development. A/RES/70/1, United Nations. sustainabledevelopment.un.org

UN (2019) The Sustainable Development Goals Report 2019. United Nations, New York. https://www.unstats.un.org/sdgs/report/2019/The-Sustainabl e-Development-Goals-Report-2019.pdf. Accessed 15 Apr 2020

UNHCR Greece (2020) Population breakdown in ESTIA Accommodation Scheme as of 10 March 2020. https://www.data2unhcrorg/en/docum ents/download/74504. Accessed 11 Mar 2020

Wang Q, Yamashita M (2015) Social-ecological evolutionary resilience: a proposal to enhance "Sustainability Transformation" about theoretical foundation. Open Access Library J. 2:e1426. https://doi.org/10.4236/oalib .1101426

WEF (2019) The Global Risk Report 2019. 14th Edition. World Economic Forum, Geneva. http://www3.weforum.org/docs/WEF_Global_Risks_Repor t_2019.pdf. Accessed 15 Apr 2020

Williams T, Hardison P (2013) Culture, law, risk and governance: contexts of traditional knowledge in climate change adaptation. Clim Chang 120(3):531-544. https://doi.org/10.1007/s10584-013-0850-0

Yamagata Y, Sharifi A (eds) (2018) Resilience-oriented urban planning: theoretical and empirical insights. Springer, Switzerland

Yiannakou A (2020) Urban regeneration as a perpetual planning process: understanding the role of stakeholders in property-led regeneration projects in Greek cities. Local Econ 35(2):83-104. https://doi. org/10.1177/0269094220914470

Yiannakou A, Salata KD (2017) Adaptation to climate change through spatial planning in compact urban areas: a case study in the City of Thessaloniki. Sustainability. https://doi.org/10.3390/su9020271

Zhang X, Li H (2017) Urban resilience and urban sustainability: what we know and what do not know? Cities 72:141-148. https://doi.org/10.1016/j.citie s.2017.08.009

\section{Publisher's Note}

Springer Nature remains neutral with regard to jurisdictional claims in published maps and institutional affiliations. 